\title{
Geophysical perspective on the structural interference zone along the Neoproterozoic Brasília and Ribeira fold belts in West Gondwana
}

\author{
A pespectiva geofísica sobre a zona de interferência \\ estrutural entre os cinturões de dobramento \\ neoproterozóicos Brasília e Ribeira no Gondwana Oeste \\ João Gabriel Motta ${ }^{1 *}$, Norberto Morales ${ }^{2}$, Walter Malagutti Filho
}

\begin{abstract}
The Brasília and Ribeira fold belts have been established in south-southwestern São Francisco Craton during the Brasiliano-Pan African orogeny (0.9-0.5 Ga - Tonian to Cambrian), and played an important role in West Gondwana continent assembly. The region is given by a complex regional fold and thrust belt superposed by shearing during the orogeny late times, with superposing stress fields forming a structural interference zone. These thrust sheets encompasses assemblies from lower- to upper-crust from different major tectonic blocks (Paranapanema, São Francisco), and newly created metamorphic rocks. Re-evaluation of ground gravity datasets in a geologically constrained approach including seismology (CRUST1 model) and magnetic data (EMAG2 model) unveiled details on the deep- crust settings, and the overall geometry of the structural interference zone. The Simple Bouguer Anomaly map shows heterogeneous density distribution in the area, highlighting the presence of high-density, high metamorphic grade rocks along the Alterosa suture zone in the Socorro-Guaxupé Nappe, lying amid a series of metasedimentary thrust scales in a regional nappe system with important verticalization along regional shear zones. Forward gravity modeling favors interpretations of structural interference up North into Guaxupé Nappe. Comparison to geotectonic models shows similarities with modern accretionary belts, renewing the discussion.
\end{abstract}

KEYWORDS: modeling; gravity; magnetics; thrust tectonics; shear zones.

\begin{abstract}
RESUMO: Os cinturōes de dobramento Brasilia e Ribeira foram estabelecidos na porção sul-sudoeste do Cráton Säo Francisco durante a orogenia Brasiliana-Pan Africana (0,9-0,5 Ga-Toniano ao Cambriano) e tiveram um importante papel na colagem do continente Gondwana Oeste. A regiáo apresenta um complexo cinturão de dobras e empurróes regionais que foram superpostos por cisalhamento nos termos finais desta orogenia, com atuação de campos de esforço de diferentes orientaçōes e resultando em uma zona de interferência estrutural. Estas escamas de empurrão compreendem assembleias de crosta inferior a superior de diferentes blocos tectônicos (Paranapanema, Säo Francisco) e rochas metamórficas geradas durante este evento. A reavaliação de dados de gravimetria terrestre com uma abordagem orientada pelo conhecimento geológico, informação sismológica (modelo CRUST1) e dados magnéticos (modelo EMAG2) revelou detalhes da configuração da crosta profunda e a geometria da zona de interferência na regiäo. O mapa de anomalia de Bouguer Simples mostra uma distribuição heterogênea de densidade na área, salientando a presença de rochas de alta densidade e grau metamórfico ao longo da zona de sutura de Alterosa, disposta sobre a Nappe de Socorro-Guaxupé e entre uma série de escamas de rochas metassedimentares em um sistema de nappes com importante verticalização dos pacotes ao longo das zonas de cisalhamento regionais tardias. Modelos diretos sobre os dados gravimétricos favorecem a interpretação de interferência estrutural até o Norte da nappe de Guaxupé. A comparação com modelos geotectônicos aponta similaridades com cinturóes acrecionários modernos e renova a discussäo.
\end{abstract}

PALAVRAS-CHAVE: modelagem; gravidade; magnetismo; tectônica de empurráo; zonas de cisalhamento.

\footnotetext{
${ }^{1}$ Programa de Pós-Graduação em Geociências, Instituto de Geociências, Universidade Estadual de Campinas - UNICAMP, Campinas (SP), Brazil. E-mail: jgmotta@gmail.com 2Departamento de Petrologia e Metalogenia, Instituto de Geociências e Ciências Exatas, Unesp, Rio Claro (SP), Brazil. E-mail:nmorales@rc.unesp.br ${ }^{3}$ Departamento de Geologia Aplicada, Instituto de Geociências e Ciências Exatas, Unesp, Rio Claro (SP), Brazil. E-mail: malaguti@rc.unesp.br *Corresponding author.

Manuscript ID: 20160144. Received in: 07/22/2016. Approved in: 02/08/2017.
} 


\section{INTRODUCTION}

Geophysical modeling is an approach to get an insight into Earth's crust architecture based on indirect information by means of its physical properties, contributing to classical structural geology evaluations (Jessell \& Valenta 1996, Jessell \& Jessell 2001). Gravity modeling applications are widespread as data are relatively easy to access via public surveys, with well-established and powerful processing techniques becoming faster and reliable (Nabighian et al. 2005a), also in integrative interpretation in Global Information Systems and 3D-modeling suites. The use of geophysics presents a possibility to unveil crust geometry with patterns sometimes not envisioned just on field observation, such as effects caused by overburden or cryptic structures (Nabighian et al. 2005a,b, Thomas et al. 2008, Stewart \& Betts 2010).

The South American platform main crustal growth episode took place in the Brasiliano-Pan African event, spanning from Rodinia breakup in Tonian through West Gondwana (Fig. 1) assembly in Cambrian (Almeida et al. 1981, 2000, Brito Neves \& Fuck 2013). Neoproterozoic collision and accretion tectonics resulted in a collage of several elements ageing from Archean to Mesoproterozoic due to diachronic basin formation, its deformation and closure (Brito Neves et al. 1999, Cordani \& Sato 1999, Strieder \& Suita 1999, Campos Neto \& Caby 2000).

This work provides renewed insight into the geophysical framework of the Tocantins and Mantiqueira orogenic systems (Fig. 1) around the Archean São Francisco Craton Southern margin. Its evolution is under discussion since the first widescale work by Almeida et al. (1981) being successively reappraised (Almeida et al. 2000, Brito Neves et al. 1999) and recently reviewed on Brito Neves and Fuck (2013, 2014), highlighting its diverse geo-chronological inventory. In fact, most information derives from geochemistry and geochronology in a poorly developed scenario of integrative discussion of structural geology and geophysics. The later counts on contributions by Haralyi and Hasui (1982), Hasui et al. (1993), Mantovani and Brito Neves (2005) and Mantovani et al. (2005) dealing with tectonic elements outline such as cratonic blocks, regional suture zones and fold belts. Although present knowledge on tectonic and structural development during this orogeny is under construction, several questions remain unanswered, mainly on geochronology and crust geometry - especially in the linking point between the two fold belts, which constitutes a structural interference zone (Trouw et al. 2013). A point to stress is that the re-evaluation of previous data, discussed with new evidences from different data sources, presents a good opportunity to settle past questions.

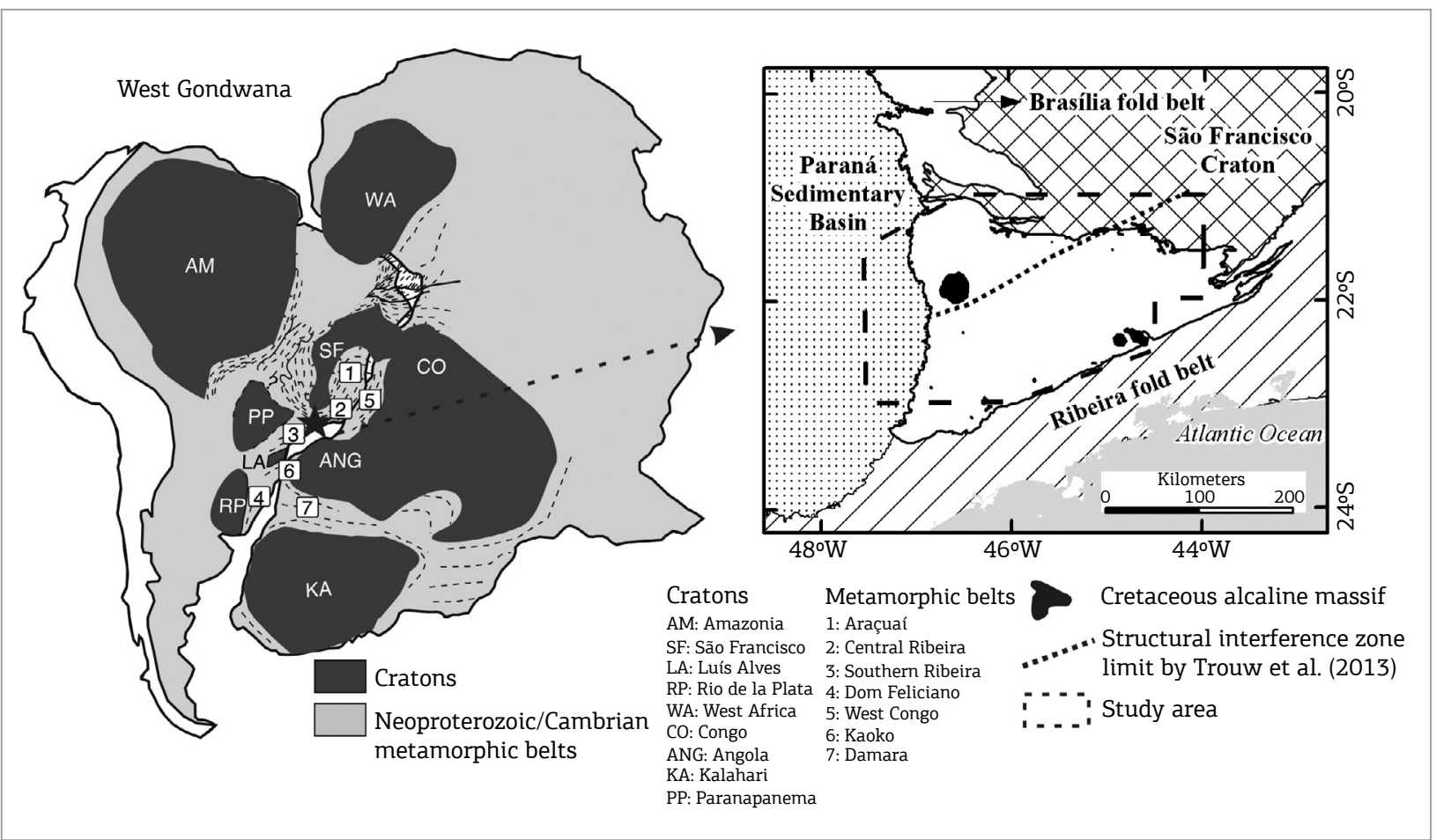

Figure 1. Tectonic elements of West Gondwana (left) and study area (right). Source: left) modified from Heilbron et al. (2008), right) according to Bizzi et al. (2001) and Trouw et al. (2013). 


\section{Geological framework}

The most of the structural framework in Brazilian crust dates back to the Neoproterozoic Brasiliano/Pan-African event (from 0.9 to $0.5 \mathrm{Ga}$ ) represented by Tocantins, Mantiqueira and Borborema orogens and pre-existing cratons, which undergone various degrees of reworking (Brito Neves \& Fuck 2013, 2014). The episodes of sedimentation, reworking, accretion and magmatism throughout the complete geotectonic cycle were diachronic, spanning from Tonian to Early Cambrian with a complex structural evolution (Morales 1993, Brito Neves et al. 1999, Strieder \& Suita 1999, Brito Neves \& Fuck 2013, 2014).

The São Francisco Craton presents tonalite-trondhjemite-granodiorite gneissic associations, migmatites, and metamorphosed granitoids from Meso- to Neo-Archean, including greenstone belt remnants, being also reworked in its borders during the Brasiliano event with intense shearing (Brito Neves
\& Cordani 1991, Teixeira \& Figueiredo 1991, Trompette et al. 1992, Romano et al. 2013). Romano et al. (2013) considers the São Francisco craton stabilization age as prior to $2100 \mathrm{Ma}$.

The Brasilia Fold Belt represents Tocantins province southern branch, and is given by metasedimentary and metavolcanic rocks thrusted forward São Francisco Craton western side, meanwhile Ribeira and Araçuaí fold belts are situated in its eastern flank (Almeida et al. 1981, 2000, Brito Neves \& Fuck 2013, 2014).

The Brasília Fold Belt comprises a thrust and fold belt presenting thin-skin (northern to central segments, 650-610 Ma) and thick-skin tectonics characteristics (southern portion, up to $530 \mathrm{Ma}$ in age) (Lama et al. 1998, Strieder \& Suita 1999, Campos Neto \& Caby 2000, Campanha \& Brito Neves 2004, Valeriano et al. 2008).

The Southern Brasília belt (Fig. 2) presents a discontinuous stratigraphy and overlays the reworked São Francisco

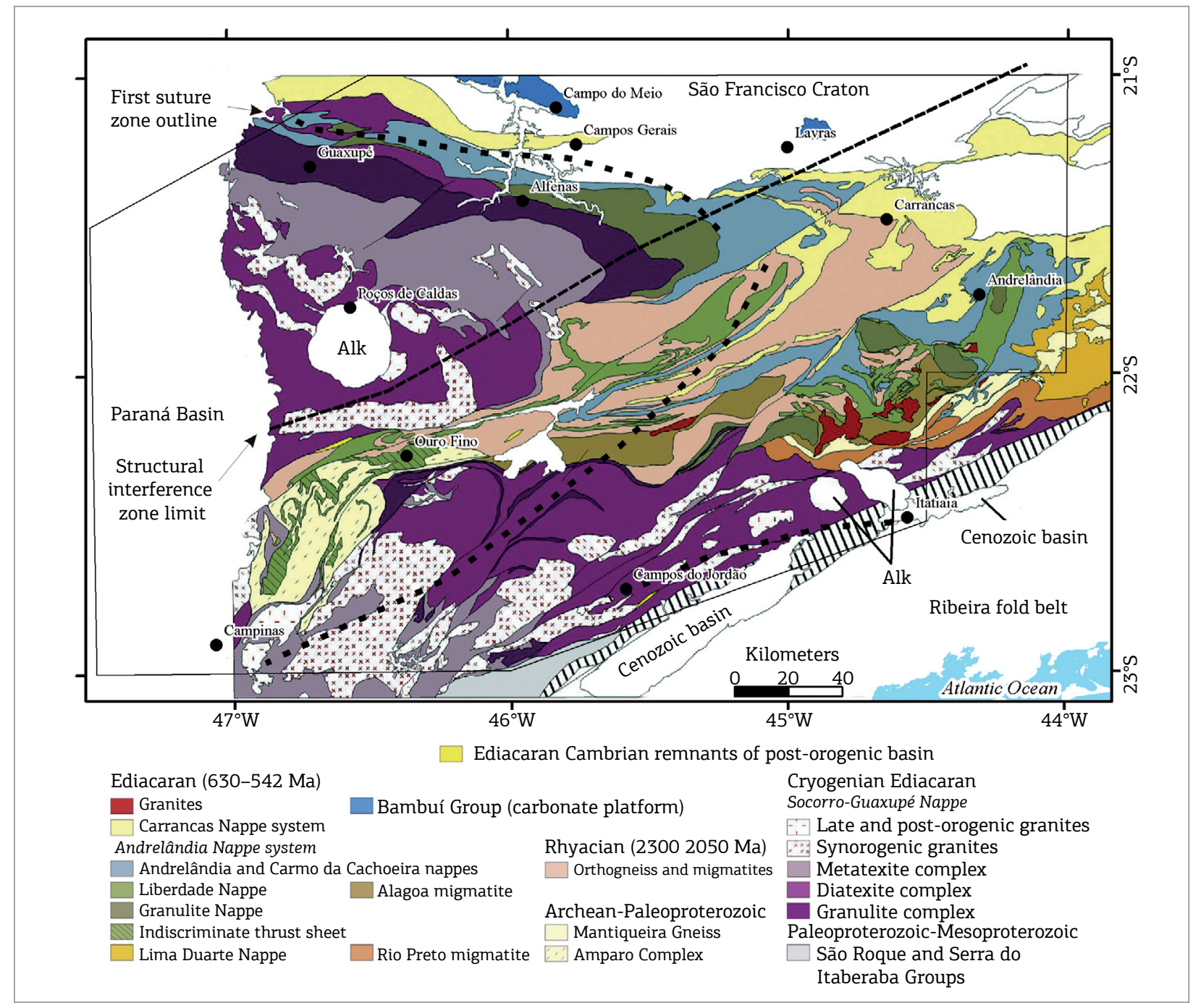

Figure 2. Tectono-stratigraphic units along southern Brasília thrust and fold belt with study area outline (dashed line). Note that 'alk' stands for Cretaceous alkaline massifs. Modified from Trouw et al. (2013). Black dots for cities, black dashed line for the structural interference zone according to Trouw et al. (2013), long dashed black line for the suture zone outline by Malagutti Filho et al. (1996) and black continuous outline for the study area. 
Craton, and is covered itself by the younger Ribeira Fold Belt (590-550 Ma) metasedimentary thrust stacks (Embu and Paraíba do Sul terranes), although a precise limit between Brasília and Ribeira fold belts is still discussed (Heilbron et al. 2008, Trouw et al. 2013). The metasedimentary nappes along the intervening fold and thrust belts are interpreted as former oceanic systems that existed along São Francisco and Paranapanema cratons borders since its sedimentary provenience and age relationships are similar, despite debate on thrust stack stratigraphy (Ebert \& Hasui 1998, Peternet et al. 2005, Heilbron et al. 2008, Hasui 2010, Campos Neto et al. 2011, Trouw et al. 2013, Westin \& Campos Neto 2013). Previous structural continuity was obliterated by tight folding and regional branching shear belts from Late-Neoproterozoic to Cambrian in two regional scale near vertical systems (Ebert \& Hasui 1998) - Campo do Meio (mostly E-W) and Paraíba do Sul (NE-SW) — due to late-orogenic lateral adjustments between São Francisco and Congo cratons. The products of this collision and lateral movement, the Socorro-Guaxupé and Andrelândia nappes, presents low-angle, southwest dipping nappe stacks superposed with sinistral shear deformation along Campo do Meio Shear Belt (Ebert \& Hasui 1998).

Nappe systems tectono-stratigraphy is given by the rootless Andrelândia Nappe System in the bottom, Carrancas and Lima Duarte Nappe systems in middle levels, including preserved autochthonous sections, and Socorro-Guaxupé in the uppermost part (Campos Neto et al. 2011, Trouw et al. 2013). Andrelândia Nappe System comprises five thrust slices named in structural upward succession as Lima Duarte, undifferentiated/ indiscriminate, granulitic, Liberdade and Andrelândia- Carmo da Cachoeira. They comprise rocks varying from siliceous and chemical metasediments to ortho-derived metamorphic rocks on greenschist to high-pressure granulite facies (including eclogites) and migmatites (Alagoa and Rio Preto), juxtaposed by thrust surfaces (Campos Neto et al. 2007, 2011). Carrancas and Lima Duarte nappe systems represent the intermediate-level thrust sheets, with quartzites, graphite schists, marbles, ultramafic schists and paragneisses up to amphibolite facies, besides it is also found as autochthonous cover over São Francisco Craton (Campos Neto et al. 2011). Socorro-Guaxupé Nappe comprises an allochthonous lower crust slice, with high pressure/temperature facies metamorphism, given by metatexites, diatexites and granulites with magmatic arc affiliation $(-630 \mathrm{Ma})$ which are older than the metasedimentary nappes (560 Ma) (Campos Neto \& Caby 1999, 2000, Campos Neto et al. 2011).

Expressive sin- to post-orogenic, alkaline to calc-alkaline, acid magmatism took place on subduction-related settings in Paraíba do Sul Shear Belt and Socorro-Guaxupé Nappe from Criogenian to Ediacarian forming several suites and massifs, being emplaced mainly along shear zones with inheritance from Mesoproterozoic basement (Ebert et al. 1996, Sial et al. 1999, Mora et al. 2014).

The Alterosa Suture Zone gives the limit between São Francisco and Paranapanema blocks by the end of the Neoproterozoic, comprising the remainder of the subduction zone (Malagutti Filho et al. 1996, Ebert \& Hasui 1998). The Alterosa Suture Zone trace is given by granulites from the bottom of Socorro-Guaxupé Nappe and has been modified by extensive NE-SW shear belts (Ebert $\&$ Hasui 1998, Campanha \& Brito Neves 2004). Eclogites and other lower level crustal rocks are also found in the Andrelândia Nappes System indicating high pressure levels and crust subduction (and therefore, obduction) on the eastern collision front from the Congo Craton, involving middle-crust thrust slicing from 618-575 Ma (Campos Neto et al. 2011).

The older Amparo Complex and Rhyacian orthogneisses comprises high grade gneissic rocks with complex tectonic relationships that occur as slices between the lobes of Socorro-Guaxupé Nappe, mainly differing from the structural settings of the Neoproterozoic units (Heilbron et al. 2008, Valeriano et al. 2008).

The Bambuí Group overlies São Francisco Craton as an extensive low-grade to non-metamorphic mixed-siliciclastic and carbonatic Neoproterozoic platformal cover, with minor deformation in the Brasiliano/Pan-African event (Martins-Neto 2009).

In contrast to the Western part of the South American Platform, the Brazilian crust remained mostly absent of deformation throughout Phanerozoic, except for the formation of several sedimentary basins, and magmatic events developed by far-field stress deformation from the Andean chain (Stampfli et al. 2013, Granot \& Dyment 2015). From Neo-Ordovician to Neo-Cretaceous the siliciclastic Paraná intra-cratonic basin is formed over Precambrian crust (mainly Paranapanema Block and adjacent fold belts), also hosting the expressive Serra Geral Formation basic magmatism (dykes, sills and basalts) from Lower Cretaceous (Zalan et al. 1990, Peate 1997). Alkaline magmatism took place during Upper Cretaceous over both metamorphic basement and Paraná Sedimentary Basin, with several volcanic and plutonic members given by alkaline massifs in the study area (Ulbrich and Gomes 1981) - Poços de Caldas (larger on west side, Fig. 2), Itatiaia (the larger in southeast) and Passa Quatro. Further evolution comprises South Atlantic Ocean opening from Cretaceous to the present, including complete break-up of Pangea and oceanic expansion (Granot \& Dyment 2015). 


\section{Geophysical framework}

Geophysical approaches to the Southeastern South American platform started in 1980's engaging on regional structural-geotectonic elements outline (Lesquer et al. 1981, Haralyi \& Hasui 1982). From 1990's to 2000's efforts gradually focused to more specific elements in the crust (Hasui et al. 1993, Malagutti Filho et al. 1996, França \& Assumpção 2004, Slavec et al. 2004, Mantovani et al. 2005), returning to regional scale works by seismology and potential field methods in the 2010's (Assumpção et al. 2013a, 2013b, Chulick et al. 2013, Marangoni \& Mantovani 2013, van der Meijde et al. 2013, 2015).

Lesquer et al. (1981) presents first the interpretations over Southern São Francisco Craton geometry, observing a NW-SE Neoproterozoic structural imprint on gravity data over its Archean grain, suggesting the existence of a WNW-ESE trending suture zone (Alfenas granulitic belt). Haralyi and Hasui (1982) provided gravity interpretations of the Archean-Proterozoic framework in eastern Brazil. They describe the presence of a (stable) crustal block marked by a very low Bouguer Anomaly, corresponding to Sâo Francisco Craton with crustal thickening, which is surrounded by higher density belts relating to metamorphic belts with high-grade elements formed in the BrasilianoPan Africano event. The authors interpret these higher signal zones as suture zones (Alterosa suture zone) which corresponds to the Alfenas Granulitic Belt by Lesquer et al. (1981).

Hasui et al. (1993) proceeded into a more detailed assessment of the crust established during Brasiliano/Pan-African, outlining different orogenic belts, stable entities and regional lineaments with more detail, including geochronological evidences, and developing geotectonic reconstructions further into the plate tectonics panorama. Further work by Malagutti Filho et al. (1996) lacks detail into crustal structure along the subduction zone between São Francisco Craton and the Paraná-Paranapanema Block (Alterosa Suture). Their crustal duplication model depicts the high-grade granulites being thrust up the São Francisco Craton, with crustal thickness varying from 40 to $30 \mathrm{~km}$ (thinning to southeast), and including the suture zone displacement along Campo do Meio shear belt. Evidence for the concealed Paranál Paranapanema block emerges from gravity processing for the Paraná Sedimentary Basin effect removal (Mantovani et al. 2005, Mantovani \& Brito Neves 2005). Their results suggests the block outline as a NE-SW wedge-like feature that acted as an obducted block in relation to São Francisco Craton, with its exposed roots at Socorro-Guaxupé Nappe, in agreement to previous interpretations (Malagutti Filho et al. 1996, Brito Neves et al. 1999).

Estimates for Mohorovičić (Moho) discontinuity depth varies from 34 to $43 \mathrm{~km}$ with thicker crust along both
São Francisco craton and Paraná Sedimentary Basin, and thinning over the Neoproterozoic belts and the Atlantic coast (França and Assumpçao 2004; CRUST1 model - 1 degree global crustal model by Laske et al. 2012, Assumpção et al. 2013a, Chulick et al. 2013, van der Meijde et al. 2013). Several crustal thickness and mantle structure models are available proving consistent, besides differing input datasets, constraining parameters, physical property nature, sample density and data distribution (Assumpção et al. 2013b, van der Meijde et al. 2015).

Regarding the Cretaceous alkaline intrusions geophysical responses, Marangoni and Mantovani (2013) points out that its emplacement was strongly influenced by basement and basin structures interpreted on magnetic and gravity data over the N125 mantle-plume trace azimuth as previously envisaged (Ulbrich \& Gomes 1981). Gravity modeling estimates for Poços de Caldas alkaline massif depth ranges from 7 to $8 \mathrm{~km}$, with a maximum $(17 \mathrm{~km})$ in its center (Slavec et al. 2004).

\section{DATA AND METHODS}

Gravity is a quite simple physical property to interpret as it present straightforward relationships in geological contexts relating to density of earth materials, nevertheless, caution is advised for subjectivity and ambiguity issues (La Fehr \& Nabighian 2012). Gravity data processing is a well-established procedure with plenty resourceful descriptions of mathematical aspects, method revisions and good practices (Blakely 1996, Milligan \& Gunn 1997, Nabighian et al. 2005a, La Fehr \& Nabighian 2012). Processing and interpretation of magnetics and gravity data follows the potential field theory and and are described by relatively similar mathematical operations (Blakely 1996).

Gravity data used in this contribution are given by 1214 ground stations from Universidade de São Paulo (USP) Instituto de Astronomia, Geofísica e Ciências Atmosféricas (São Paulo - Brazil) database acquired with varying station spacing from 8 to $20 \mathrm{~km}$ (Fig. 3). The dataset comprises surveys back to 1960's and includes data from Malagutti Filho et al. (1996). These data are stored in tables with location for each station, gravity measurements and its reduced form by International Union of Geodesy and Geophysics 1967 gravity formula and values for Simple Bouguer anomaly $\left(2670 \mathrm{~kg} \cdot \mathrm{m}^{-3}\right.$ density) calculated over altimeter elevation data. Gravity station data interpolation to a surface took place in $4 \mathrm{~km}$ cell-size array with the minimum curvature algorithm (Briggs 1974). Geophysical data processing took place on Geosoft Oasis Montaj platform, with information 
layers integration on ESRI Arc Map ${ }^{\mathrm{TM}}$ GIS system for comparison to geological data.

Earth Magnetic Anomaly 2-arc min grid (EMAG2, Maus et al. 2009) accounts for a magnetic data compilation collected around the globe by different platforms, mainly ground, satellite and airborne, integrated into a 2 arc-minute resolution surface referenced $4 \mathrm{~km}$ above the geoid, and containing long wavelength information $(>330 \mathrm{~km})$ from satellite data. The interpretation of the magnetic geophysical method has been reviewed in Blakely (1996) and Nabighian et al. (2005b). These data are useful for deep crust magnetic structure observation, displayed for comparison to the features observed on geology, gravity and crustal thickness data. EMAG2 data are hosted in GMT (Wessel \& Smith, 2013) software-compatible gridded surfaces for visualization. CRUST1 model (Laske et al. 2012), data comprises point information on crustal thickness (Moho-depth) determinations by seismology studies for a world-wide model from several sources (active, passive, long and short-term stations). These data were interpolated into 1-degree cell size surfaces with the minimum curvature algorithm (Briggs 1974). The discussion of the development of both EMAG2 and CRUST1 models is not intended in this contribution and reader should refer to the mentioned publications.
Preliminary observation of the gravity dataset showed presence of high-frequency noise over some data stations. Its analysis with the Power spectrum method (Spector \& Grant 1970) in a gridded surface allowed identification of spurious high-frequency noise. The spurious data have been suppressed through Nyquist frequency removal by low-pass filtering with 0.06-cycle frequency cut-off, resulting in the Simple Bouguer Anomaly map refered from here onwards as Bouguer Anomaly (Fig. 4). This map presents smooth contours, being absent of local high amplitude artifacts.

Two and a half dimensional modeling took place in Geosoft's Oasis Montaj GM-SYS platform over information on the Simple Bouguer anomaly map (Fig. 4) being constrained by geology information based on a geological map by Trouw et al. (2013) (Fig. 2) and interpretations as previously exposed in the geological framework section. Data from CRUST1 model were used to constrain Moho discontinuity depth. Three geological sections (Fig. 4) have been modeled with reference density information from compilations by Carmichael (1989), Telford et al. (1990) and Turcotte and Schubert (2002) and a paper by Slavec et al. (2004) - see details in Table 1. GM-SYS forward modeling platform is an iterative environment for potential field data modeling which complies with Talwani et al. (1959) and Won and Bevis (1987) proposals for anomaly calculation.

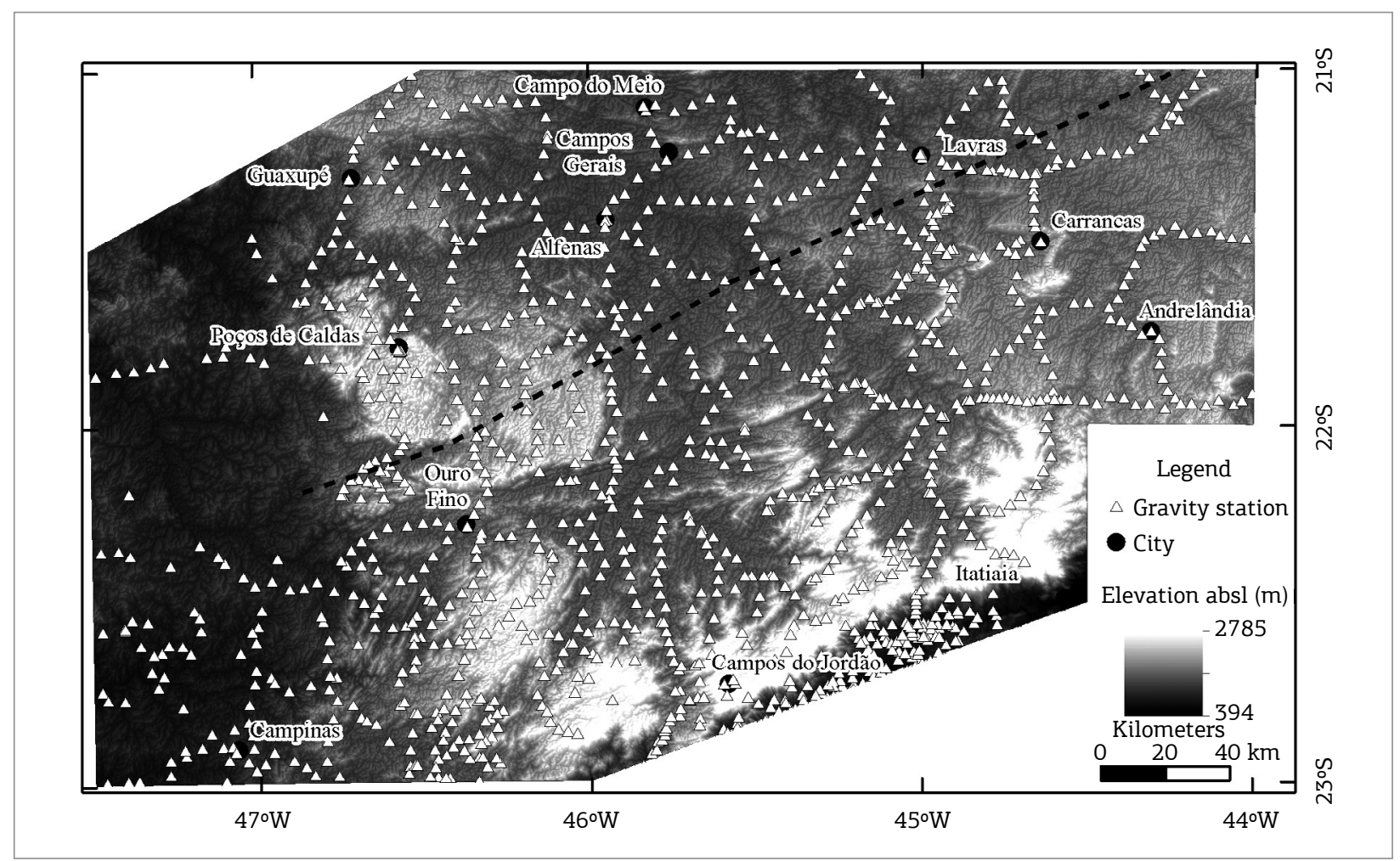

Figure 3. Gravity data station location over SRTM digital elevation model. Black dashed line for the structural interference zone according to Trouw et al. (2013). 


\section{GRAVITY RESULTS}

Results comprise qualitative interpretations over Bouguer Anomaly maps and forward models in the following sections unveiling the geometry of the structural interference zone.

\section{Bouguer anomaly maps}

The Bouguer Anomaly (Fig. 4) varies from - 125.8 to $-59.6 \mathrm{mGal}$ in the area, showing complex outlines due to different density assemblages and the superposition of the structural grains. Gravity domains trends NE-SW, NW-SE and N-S similar to mapped geology, despite an immediate relationship is not straightforward, with regions overlapping different tectonic elements. The results are discussed in terms of its possible geological counterpart according to the geological background map (Fig. 2) by Trouw et al. (2013).

Higher Bouguer anomaly values in the area are up to $-59 \mathrm{mGal}$ and occurs in wide, E-W to roughly NE-SW trending features in the central part part of the study area (domains E and F, Fig. 4) interpreted as high- to mediumgrade metamorphics such as the Socorro-Guaxupé Nappe granulites amidst relatively less dense areas (domain C, Fig. 4). Other higher Bouguer anomaly regions along Paraná Sedimentary Basin border are considered as basic rocks (domain B, Fig. 4), or high grade nappes over São Francisco Craton or greenstone belt associations (domain H, Fig. 4).

Gravity Domain $\mathrm{C}$ is given by values lower than $-90 \mathrm{mGal}$ trending NE-SW to NNE-SSW and E-W directions corresponding to flat-lying do medium-angle, lower grade meta-sedimentary rocks from Andrelândia and Carrancas nappe systems and Lima Duarte Nappe, also ortho-derived lower crust from Socorro-Guaxupé nappe, including syn- to post-tectonic granitic bodies. Amphibolite facies Rhyacian orthogneiss- migmatite complexes and Archean gneisses from Amparo Complex and Mantiqueira Gneiss comprises this domain, with low Bouguer anomaly values along Ribeira do Sul shear belt further southeast.

Bouguer anomaly domains with values less than $-95 \mathrm{mGal}$, and circular to oval outlines (domains D and G, Fig. 4) relates to Cretaceous alkaline massifs, respectively Poços de Caldas and Itatiaia- Passa Quatro. These gravity domains reaches the minimum values observed $(-125.87 \mathrm{mGal})$ and its response is given by its lower density relative to a denser basement.

The domains with higher values in Bouguer Anomaly ( $\mathrm{E}$ and $\mathrm{F}$ ) shows gentle signal attenuation according to the expected dip of the thrust sheets, with the signal attenuating to the SW in $\mathrm{E}$ and to the $\mathrm{SE}$ in $\mathrm{F}$. In domain $\mathrm{C}$ there is not clear evidence for the dip of the rock packages, with high gradients in NE-SW directions, suggesting that they

Table 1. Density values for the rock unities in the modeled sections.

\begin{tabular}{|c|c|c|c|c|}
\hline Group & Rock & $\begin{array}{c}\text { Density interval } \\
\left(\mathbf{k g} \cdot \mathrm{m}^{-3}\right)\end{array}$ & Mean density $\left(\mathrm{kg} \cdot \mathrm{m}^{-3}\right)$ & Source \\
\hline Sedimentary & Sedimentary (mean) & & 2500 & 1 \\
\hline \multirow{4}{*}{ Igneous } & Diabase & $2500-3200$ & 2910 & 1 \\
\hline & Acid & $2300-3110$ & 2610 & 1 \\
\hline & Basic & $2090-3170$ & 2790 & 1 \\
\hline & Alkaline & $2470-2620$ & 2545 & 2 \\
\hline \multirow{10}{*}{ Metamorphic } & Quartzite & $2500-2700$ & 2600 & 1 \\
\hline & Schist & $2390-2900$ & 2640 & 1 \\
\hline & Gneiss & $2590-3000$ & 2800 & 1 \\
\hline & Granulite & $2670-3100$ & 2885 & 3 \\
\hline & Anfibolite & $2900-3040$ & 2960 & 1 \\
\hline & Eclogite & $3200-3540$ & 3370 & 1 \\
\hline & Metamorphic (overall) & $2400-3100$ & 2740 & 1 \\
\hline & Supracrustal (overall) & & 2700 & 4 \\
\hline & Metacarbonate & $2600-2900$ & 2750 & 1 \\
\hline & Metagraywacke & $2600-2700$ & 2650 & 1 \\
\hline Mantle & Upper & & 3250 & 5 \\
\hline \multirow{2}{*}{ Crust (overall) } & Upper crust & & 2730 & 4 \\
\hline & Lower crust & & 2850 & 4 \\
\hline
\end{tabular}

Sources: 1) Telford et al. (1990); 2) Slavec et al. (2004); 3) Carmichael (1989); 4) Malagutti Filho et al. (1996); 5) Turcotte \& Schubert (2002). 
have near-vertical geometry, which is evidenced by geological information regarding its position centered in the shear belt system.

Two gravity domains with Simple Bouguer Anomaly ranging from -95.0 to $-80 \mathrm{mGal}$ occur in the western flank of the area relates to Paraná Sedimentary Basin (A and B, Fig. 4). Domain A represents a region of thicker sedimentary section (from basal Itararé Group to the Pirambóia Formation) underlain by basic volcanics, meanwhile Domain $\mathrm{B}$ complies with a thinner sedimentary pile and preponderant response from the basic rocks in Serra Geral Formation. An alternative for the higher gravity values in domain $\mathrm{B}$ is the presence of relatively shallow high-grade basement near to the basin border. The latter hypothesis seems feasible as the B domain extends from the basin to the North-Northeast into the Neoproterozoic metamorphic basement.

Considering Bouguer Anomaly along the structural interference zone, domains $\mathrm{C}, \mathrm{E}$ and $\mathrm{F}$ gives information as follows:

domain E (fig. 4) presents anomaly values up to $-59.6 \mathrm{mGal}$ in a $\mathrm{E}-\mathrm{W}$ trend representing granulitic rocks from Guaxupé Nappe, juxtaposed to Andrelândia Nappe System granulite-facies metamorphic rocks along Campo do Meio shear belt. Similar to E domain, F domain presents higher values; however, it presents a NE-SW trend, interpreted as granulite-facies metamorphic rocks from Socorro Nappe; a set of NE-SW gravity lows occurs along C domain (Fig. 4) trending parallel to Paraíba do Sul shear belt and the structural interference zone limit proposed by Ebert and Hasui (1998) and Trouw et al. (2013), being considered as expression of highly-deformed/stretched metasedimentary rock packages;

- connecting $\mathrm{E}$ and $\mathrm{F}$ domains exists a relatively higher density zone trending N-S, varying from -90 to $-80 \mathrm{mGal}$ without surface expression of expectedly relatively denser rock types, being interpreted as rocks akin to Socorro and Guaxupé nappe lobes amid the intense shearing.

\section{Forward models}

Forward modeling took place on three sections along the nappe system main trace (section 1, Fig. 5) and also orthogonal to regional shear belts (sections 2 and 3, Figs. 6 and 7) to depict the two structural patterns.

Despite that gravity data processing did not focused Moho depth determination, the gravity long wavelength signal/forms (regional field) complies with a 37 to $43 \mathrm{~km}$ seismic-modeled Moho, (CRUST1 and other models). This interface is deeper to the West beneath Paraná Basin and thins to East and Southeast in a sharp step close to São Francisco Craton. Models also shows a Moho surface given by wide arcuate segments with local pinch-up points beneath the Neoproterozoic fold and shear belt, contrasting with a linear outline bellow the Archean craton (Figs. 5 and 6).

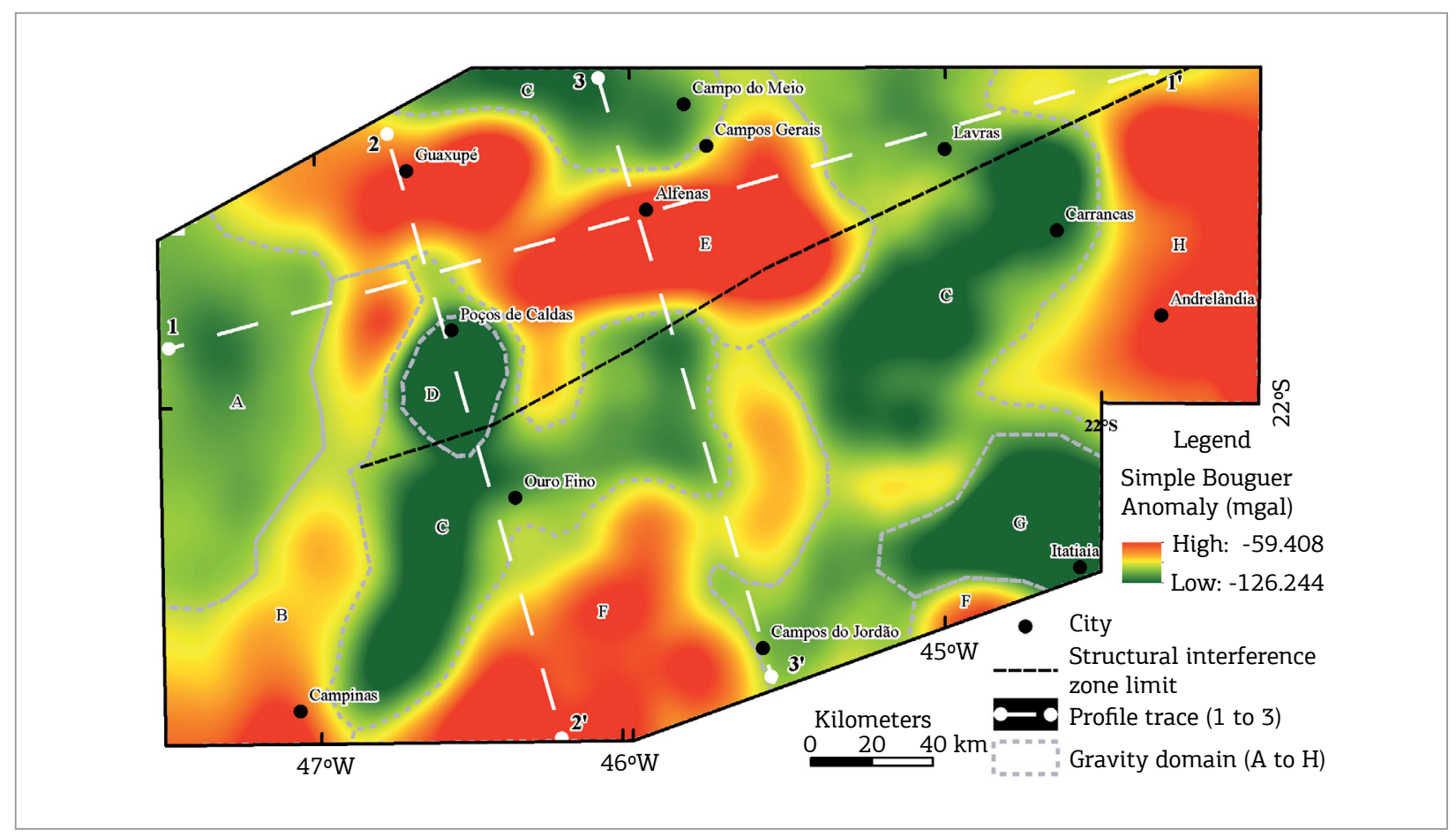

Figure 4. Bouguer Anomaly map and gravity domains in this study (dashed black lines) and modeled sections trace (dashed white lines, from 1 to 3 ). 
The first order structural trace is given by discontinuous, medium- to low- angle thrust sheets over São Francisco Craton (sections 1 and 3, Figs. 5 and 7). These thrust sheets presents flat-lying geometry with internal stack truncation, as well as rootless and folded sheets, like Andrelândia and Carrancas nappe systems (profiles 2 and 3, Figs. 6 and 7). Steepening of the thrust stacks along the Late-Neoproterozoic shear zones affects the tectonic pile from basement to the uppermost nappes, including stack truncation and affecting the Rhyacian orthogneisses and migmatites, without significant imprint in São Francisco Craton (Figs. 6 and 7).

Granulite-diatexite-metatexite lower crust associations occurs as thick low-angle nappe stacks (profiles 1 to 3 , Figs. 5 to 7) representing the higher density domains ( $\mathrm{E}$ and $\mathrm{F}$ ) on Bouguer anomaly maps, with a discontinuous outline. These lower crust stacks are part of Alterosa Suture zone (Figs. 5 to 7 ), which is juxtaposed to upper

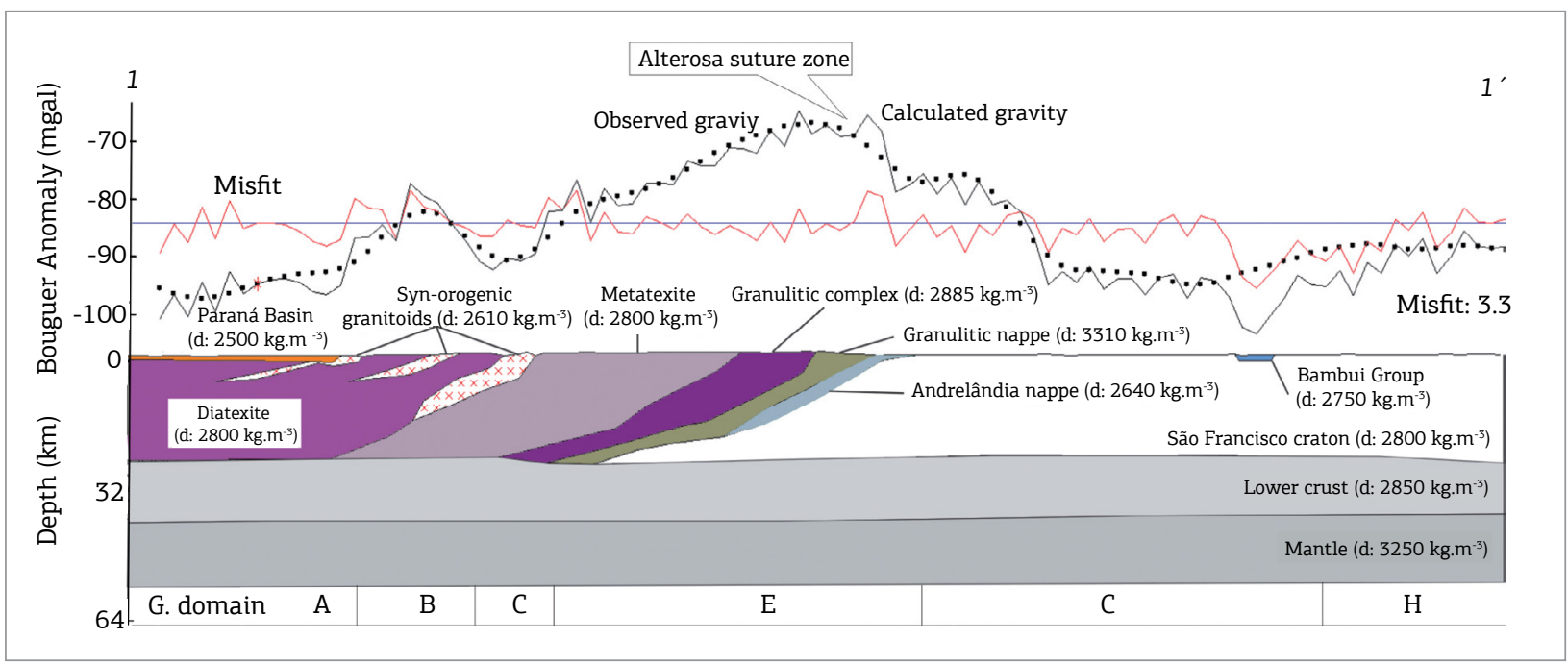

Figure 5. Forward model 1-1' along the thrust system over São Francisco Craton (see figure 4 for model location). Gravity domain limits are marked in lower level. Vertical exaggeration is 0.5.

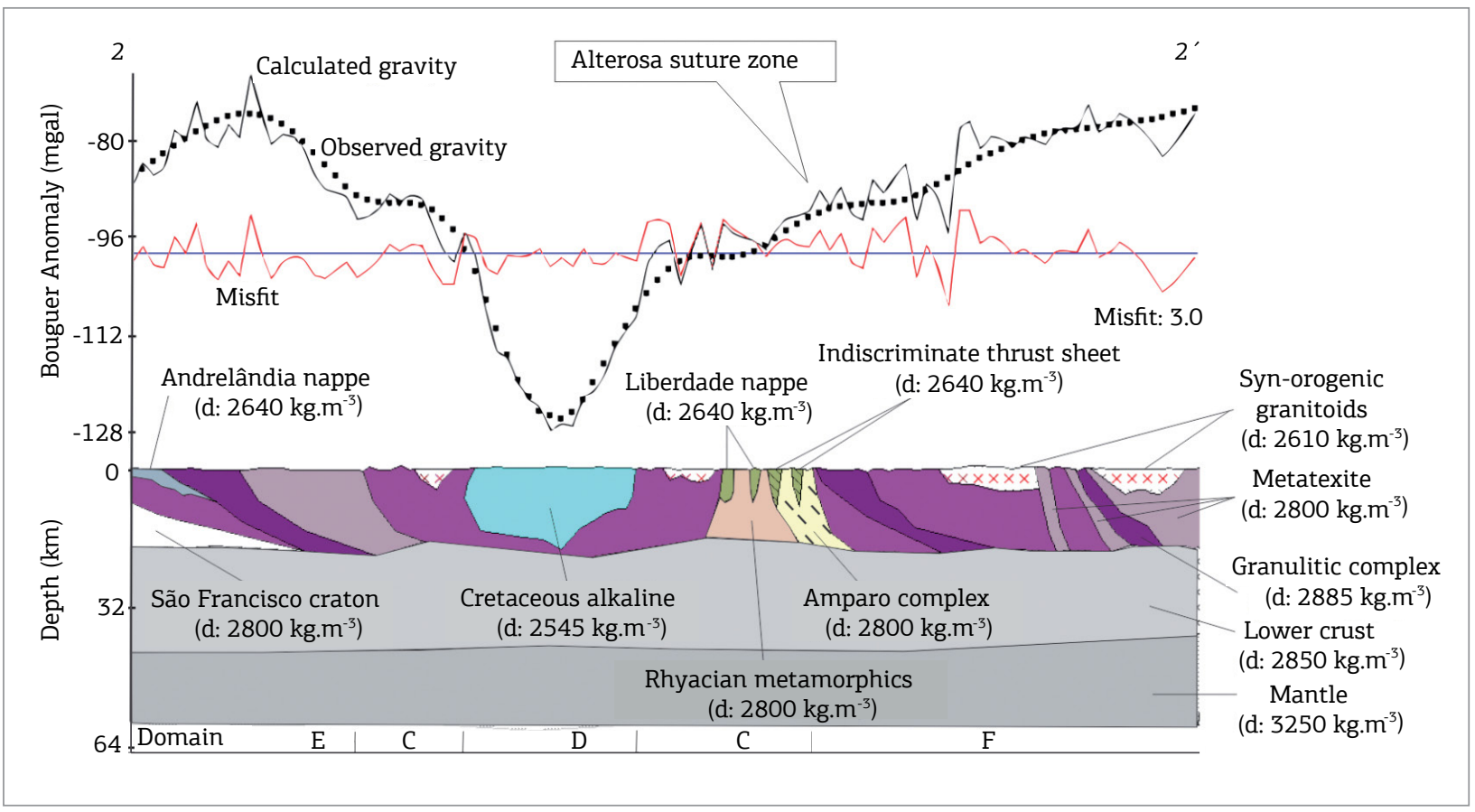

Figure 6. Forward model 2-2' orthogonal to the shearing system and fold and thrust belt (see figure 4 for model location). Gravity domain limits are marked in lower level. Vertical exaggeration is 0.8 . 
level meta-sedimentary and meta-volcanic thrust sheets from Andrelândia nappe system, and above the Guaxupé Nappe granulite slice. The granulitic nappes in profiles 1 and 3 (Figs. 5 and 7) are assigned density 3310 kg. $\mathrm{m}^{-3}$ for being described as containing eclogite levels as well.

Deformation along the shear belt incorporates older gneisses amid the nappe system, causing displacement and block isolation in an intricate array along Paraíba do Sul shear belt central displacement zone (e.g. Amparo Complex, Alagoa migmatite and Rhyacian gneisses, Figs. 6 and 7).

São Francisco craton was modeled as a straight to slightly curved block bellow the Neoproterozoic fold and thrust belts (Figs. 5 and 7) in a flat ramp-like geometry, with crust duplication of overriding lower crust nappes from Socorro Guaxupé nappe on high-grade gneisses from its infrastructure (Figs. 5 to 7 ).

Syn- to post- tectonic granites occur amid thrust sheets with bounding surfaces following thrust stacks limits, secondary thrust surfaces and shear zones, including rootless bodies (Figs. 5 and 6), hosted along past higher permeability and stress relief zones.

Paraná sedimentary basin occurs as a thin cover (Fig. 5, west flank), being modeled with a $2500 \mathrm{~kg} . \mathrm{m}^{-3}$ density, with increasing thickness to the West according to overall basin geology (Zalan et al. 1990) emplaced over high-grade associations from Guaxupé Nappe.

Poços de Caldas Cretaceous alkaline massifs appears on section 2, shaped as an voluminous irregular circular- like body and its geometry is dubious in absence of constraining evidence.

\section{DISCUSSION}

Discussion on the crustal framework and structural interference response on geophysical data follows gravity interpretations in the light of current geological models, including comparison to previous information, data from CRUST1 and EMAG2 models, and geotectonic models.

\section{Gravity and crustal framework}

Power spectrum analysis results are in the range of crustal thickness calculated via other methods, being shallower $(24 \mathrm{~km})$ than estimates in CRUST1 model ranging from 37 to $42 \mathrm{~km}$, similar to other independent studies (França \& Assumpção 2004, Assumpção et al. 2013a, Chulick et al. 2013, van der Meijde et al. 2013). Concerning the crust stabilization age (Durrheim and Mooney 1991, 1994) the Moho depth for the crust formed in Archean- and Proterozoic- ranges from 32 to $45 \mathrm{~km}$ on the first, and 42 to $55 \mathrm{~km}$ in the second. Overall lower Moho depth values are observed in the area in comparison to these reference values. São Francisco Craton crustal thickness on forward models is up to $30 \mathrm{~km}$, which is inferior to mean values for crust stabilized from 2.5 to 2.6 Ga (Abbott et al., 2013).

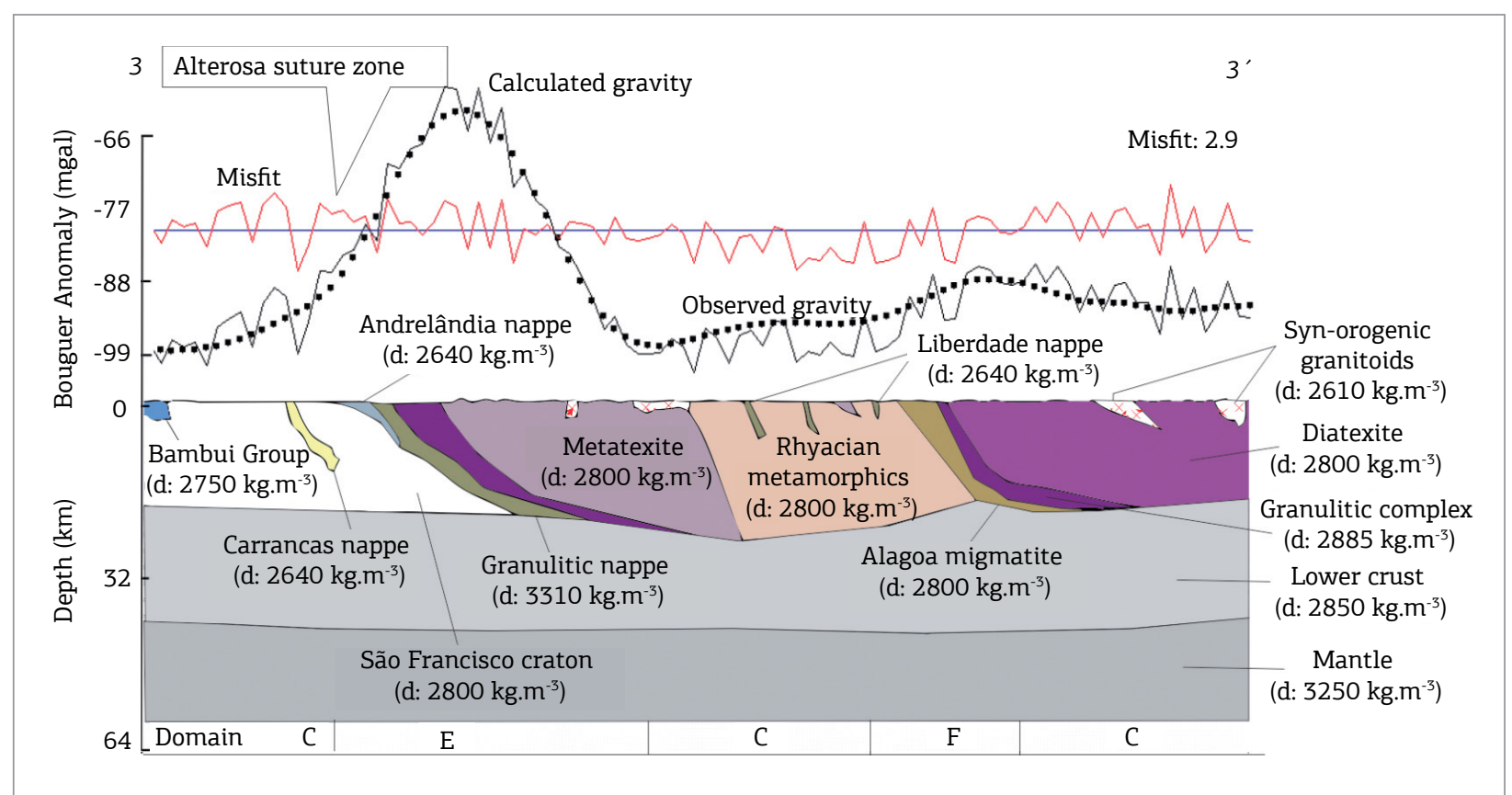

Figure 7. Forward model 3-3' along the thrust system over São Francisco Craton (see figure 4 for model location). Gravity domain limits are marked in lower level. Vertical exaggeration is 0.8 . 
The overall trace of the geophysical domains is compatible to the structural trace in shear zones and axial zones of major folds (Fig. 8). Gravity domains $\mathrm{E}$ and F relates to Alterosa Suture (Fig. 8) as an discontinuous high-density crust fragment taken as the limit for Brasília fold belt and São Francisco Craton (Alkmim et al. 1993, Malagutti Filho et al. 1996), and displaced by the sinistral- motion of Paraíba do Sul shear belt by the end of the Neoproterozoic (Ebert \& Hasui 1998). The link between the domains $\mathrm{E}$ and F, and, moreover, the Alterosa Suture are missing amid the shear system. The models constructed here indicate that Alterosa suture zone traces needs re-observation due to its structural position just below the granulite sets (bellow domains $\mathrm{E}$ and F). For suggesting the new outline of the Alterosa suture zone we followed the boundaries of domains $\mathrm{E}$ (Guaxupé Nappe) and F (Socorro Nappe). We are aware that the scale of the gravity survey and lithology maps used in our interpretation, also the density contrast of the lithologies, can differ from mapped surface geology. This suture trace is given by geophysical information and has been constrained by geological facts as long as possible.

A crustal duplex structure along the lower crust nappes and upper nappes has been proposed previously by Haralyi and Hasui (1982) and following works by Valeriano et al. (2008), Hasui (2010) and Campos Neto et al. (2011) with geochemistry constraints for deep crust involvement (Campos Neto \& Caby 1999, Iyer et al. 1996, Lama et al. 1998). Complex geometries for both thrust-folding and shear systems observed in forward models, structural and metamorphism features are expected in a continuum crustal model for orogen evolution (Boyer \& Elliott 1982, Sanderson 1984, Sylvester 1988). Syn- to late- orogenic granite bodies and massifs presents shallow roots along thrust and shear-related surfaces, confirming its relation to local magma generation and emplacement during orogeny late- stages (Ebert et al. 1996, Sial et al. 1999, Mora et al. 2014). Relationships to the different crustal levels observed and tentatively modeled in the gravity datasets are further discussed in the following section.

Survey spacing, potential field ambiguity, source body shape and superposition, along with poor density contrast are probably involved in absence of clear geophysical signatures for tectonic elements, except for high-grade metamorphic rocks and Cretaceous alkaline massifs.

\section{Deep geophysical expression of the structural interference zone}

Here we discuss the proposed outline of the Alterosa Suture zone and modeled gravity sections in the light of the Moho discontinuity (CRUST1) and magnetic anomaly (EMAG2) maps.

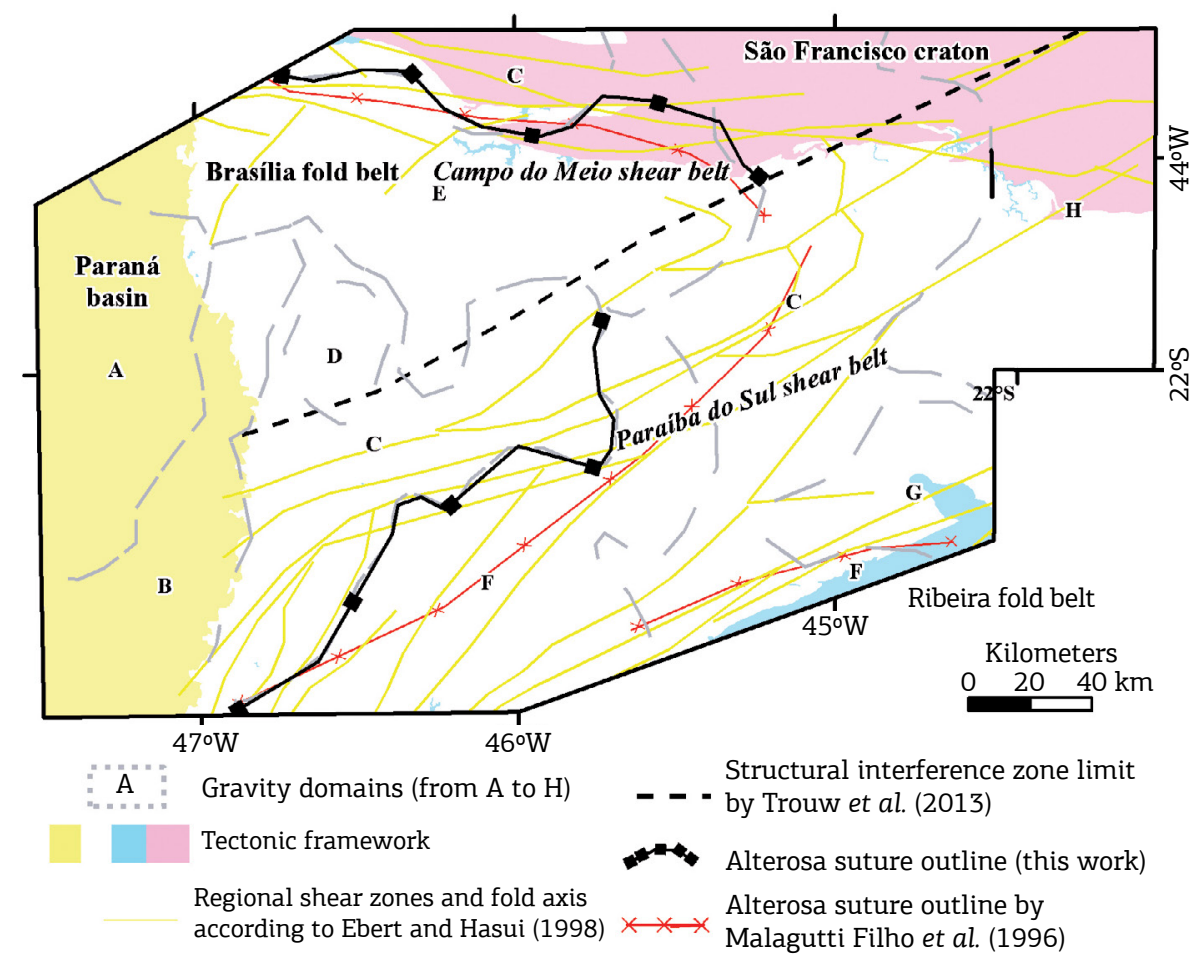

Figure 8. Gravity domains over the tectonic framework (in colors) by Almeida et al. (1981) and Bizzi et al. (2000), Alterosa suture zone proposed outlines and shear-related features. 
The discontinuous Alterosa Suture outline previously defined by Malagutti Filho et al. (1996) was redefined, with the new outline presented being situated near a crustal thinning region in crustal thickness maps, following the trace of the Moho depth contours (Fig. 9). The relationship to crustal thickness suggests that late-Neoproterozoic evolution included deeper crust re-organization or that such level of reconstruction was already established. Cenozoic alkaline magmatism could account for this discrete thinning in Sáo Francisco Craton border but needs supporting information. The discontinuity in the trace of the suture zone along with the interference zone confirms that the lateral structural system is post- kinematic in relation to the suturing event.

EMAG2 data magnetic grain shows high-magnetization areas according to regional low-angle thrust surfaces direction and to the high-angle shear systems main trace as presented by Ebert and Hasui (1998) (Fig. 9). The wedge-like continuous high magnetization zone follows the nappe system outline, with decreasing signal to the southwest (into the Paraná Sedimentary Basin) and extending further northeast into the São Francisco Craton with subdued signal. The magnetic response in the Paraná Basin is given by extreme lower values and into the Neoproterozoic regions in a cuspid shape, also beneath the Poços de Caldas alkaline massif.

Interestingly, the magnetic grain near the proposed suture zone trace (Fig. 9) is given by gentle signal decay to the SW in the Guaxupé Nappe lobe, suggesting a dip to that direction, as also argued from structural evidences, the gravity anomaly and the gravity models. For the Socorro lobe things are not that straightforward, with a general resemblance from the magnetic outline to the suture line, with more pronounced gradients in the magnetic anomaly, suggesting a dip angle not so gentle as in Guaxupé, probably due to the major influence of the Paraíba do Sul Shear Belt and the structural interference zone.

It is noteworthy that the structural interference zone limit proposed by Trouw et al. (2013) fairly centers on the high magnetization wedge-like zone, suggesting that the developing the structural interference zone did not altered its magnetic properties by giving a magnetic signature by itself. This relies on the fact that the EMAG2 model in the area is given mainly by satellite information, representing long-wavelength information - so it depicts deep crust.

Discontinuity from the high-grade nappes and São Francisco craton further north is not evident on magnetic data. This possibly

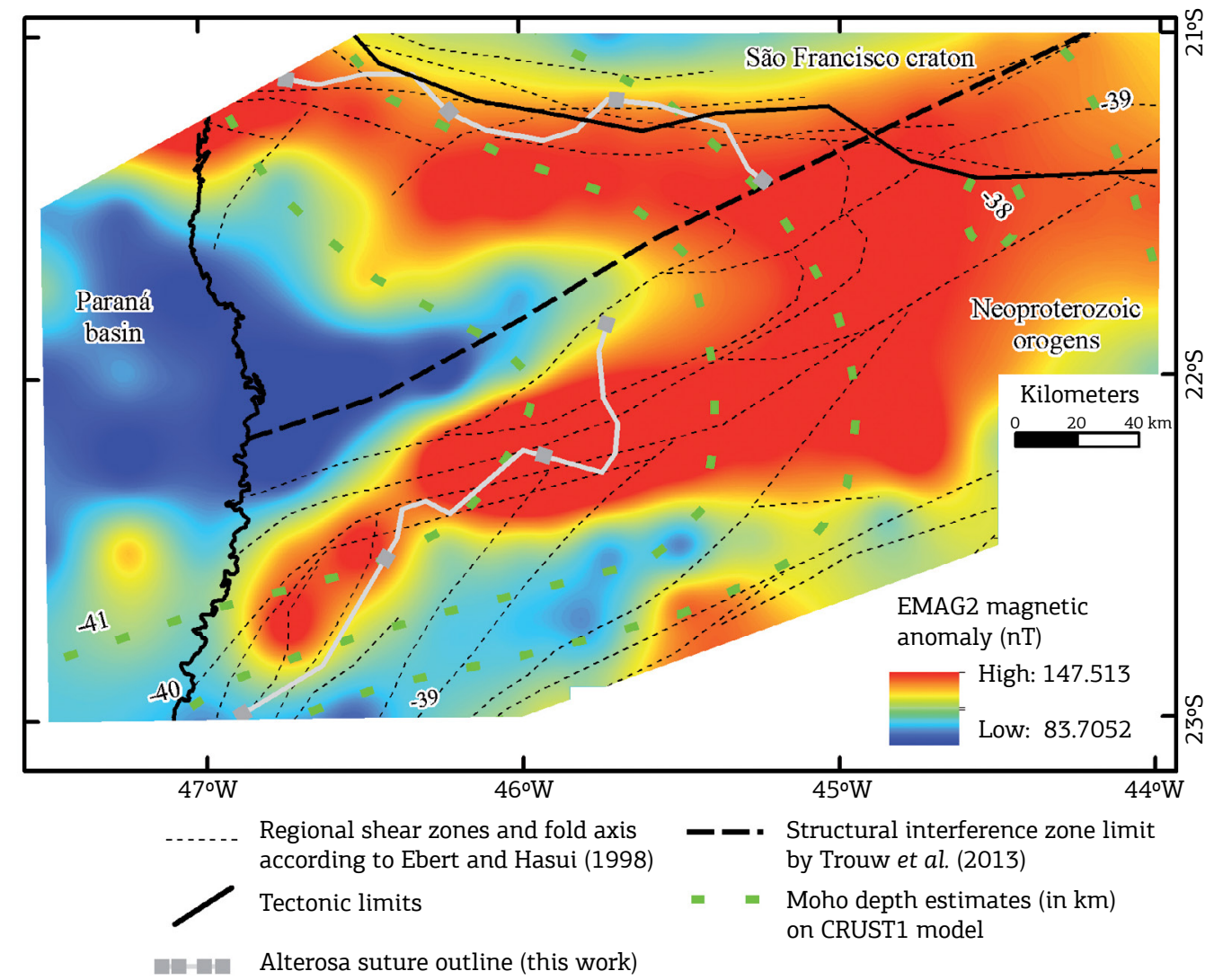

Figure 9. Structural and geophysical elements around Alterosa suture zone region. 
relates to poor magnetic contrast between the two high-grade terrains, as they comprise exposed lower crust sections commonly with high magnetization and long-wavelength signal (Shive et al. 1992). These long wavelength characteristics are products of deep-seated continental roots with its common mafic nature, rich in magnetic minerals, also Moho, upper-lower crust and Curie interface undulations, or higher metamorphic grade of deeply- eroded crust (Shive et al. 1992).

The new trace for the Alterosa suture is more conformable to the gravity, magnetic and Moho depth information, and has been conceived with geologic constraints, differing from the outline by Malagutti Filho et al. (1996). It also has a clear oblique geometry to the structural interference zone limit defined by Trouw et al. (2013) (Fig. 9). Regarding EMAG2 information a total match from the trace of the features mapped in gravity and surface geology is reasonably unexpectable given the satellite nature of the magnetic information, and presents deep crust information which implies a possible mismatch regarding dipping structures.

To define a precise structural interference zone limit by geophysical methods is challenging as it concerns a complex structural framework with weak density contrast between entities. Surface information suggests that structural interference goes further North over Socorro-Guaxupé Nappe (Peternel et al. 2005, Trouw et al. 2013), which is supported by gravity data as Alterosa suture discontinuity is fairly coincident with the proposed structural interference zone limit marked by Três Coraçóes shear zone on Paraíba do Sul shear belt (Malagutti Filho et al. 1996, Ebert \& Hasui 1998).

\section{Insights into geotectonic models}

Debate over crust- mantle interactions and its linkage to orogenesis since Archean has poor evidence for lower crust development (Windley \& Tarney 1986, Percival et al. 1992). However, present models on mantle thermal evolution and mass transfer points out to a dynamic scenario from early Earth to nowadays tectonics with different evolution of collisional systems along time, markedly post- Proterozoic orogens (Cawood et al. 2009, Abbott et al. 2013, Gerya 2014, Jamieson \& Beaumont 2013, Kamber 2015). Lower- and upper-crust sections juxtaposition by thrust systems supports its evolution by thick-skinned tectonics style (Coward 1983). This contrasts to the observation that thrust systems are common in orogens involving shallower crust conditions (thin-skinned tectonics) as observed on Brasilia Fold Belt further north from study area (Simóes 1995, Strieder \& Suita 1999, Valeriano et al. 2008). Collision tectonics models supports late-colisional continental block adjustment in large-scale shear belts, overprinting prior structural grain (Cawood et al. 2009, Gerya 2014, Jamieson $\&$ Beaumont 2013).
Large scale, late- collisional shearing on Brasília and Ribeira fold belts during lateral/oblique tectonics stages included high pressure granulites extrusion (Ebert \& Hasui 1998, Campos Neto \& Caby 2000, Lama et al. 2000) with nappe stacks being cut by near-vertical shear zones. This is a well-documented feature in linked strike-slip and thrust tectonics systems (Woodcock \& Fischer 1986, Coward 1994, Davison 1994, Woodcock \& Schubert 1994). Late-stage shearing evolution contrasts to pure fold and thrust systems proposals (Campos Neto \& Caby 2000, Campanha \& Brito Neves 2004, Campos Neto et al. 2011, Trouw et al. 2013), not accounting for the remarkable large scale Campo do Meio and Paraíba do Sul shear belts oblique motion, a fact previously discussed by Ebert and Hasui (1998).

Comparing the study area based on a geodynamic model for accretionary orogens by Jamieson and Beaumont (2013) shows similarity with large-hot orogen systems, with distinct periods of crustal material accretion involving sutures, alternating with stages of thrusting of deep crust plutonic and high grade metamorphic rocks. According to the author's Prowedge/Retrowedge/Uplifted plug/subduction Conduit (P-U-R-C) systematics, Brasília and Ribeira fold belts lies between São Francisco, and Paranapanema cratons and related African cratons (Congo) - similar to a PUR system, as follows. The closure of the former ocean took place with the fragment containing the Prowedge $(\mathrm{P})$ overriding plate forming thrust stacks (Ediacaran to lower crust ultra-high pressure Cryogenian nappe systems) and an internal and less deformed Retrowedge (R) with its subduction Conduit (C) far from the collision front, probably not outcropping today. In-between $\mathrm{P}$ and $\mathrm{R}$ segments lies an extruded bivergent Uplifted plug (U) of highly deformed, upper and lower crust nappes with the meta- sediments from the former oceanic(?) basins and interlayered granitoid bodies and extruded granulites. Late- stage Early Cambrian tectonics took place with PUR assemblage deformation by Paraíba do Sul and Campo do Meio shear belts including granitic magma intrusion along structural surfaces, with ongoing sin- to post tectonic granitic magmatism. Nowadays deep erosion levels (probably) precludes entire large- hot orogen system recognition by suppression of uppermost orogen architecture, as well as most of Uplifted plug and Retrowedge being mostly buried bellow Paraná Sedimentary Basin and demands further investigation.

\section{CONCLUDING REMARKS}

Previous geophysical crustal models (Haralyi \& Hasui 1982, Malagutti Filho et al. 1996) stands confirmed for crustal duplication and counts now with revised and detailed 
assessment, although Alterosa suture outline in southeast- to east regions still demands further scrutiny with field information and alternative geophysical approaches. Models proposed here also favors previously envisaged late-stage shearing tectonic models (Morales 1993, Ebert \& Hasui 1998), seemingly extendable to deeper levels (Boyer \& Elliott 1982, Sanderson 1984, Sylvester 1988). Shear-related structures superposes the low-lying to medium-inclined thrust stacks and controls syn- to late-tectonic granitic bodies emplacement (Ebert et al. 1996, Ebert \& Hasui 1998, Mora et al. 2014). The extension of the structural interference zone proposed by Trouw et al. (2013) stands confirmed by geophysical means, also observations by Campanha and Brito Neves (2004) are somewhat in agreement regarding the thrust system formation, and the oblique kinematics for its formation.

Thrust stacks are extended to deep levels and external/ independent information is necessary to reduce subjectivity and ambiguity inherent to the gravity interpretation (Skeels 1947, Jessell \& Jessell 2001). Gravity itself does not address entirely the structural complexity and joint interpretation. The CRUST1 model presents evidence for crustal- scale structure along the fold and thrust system limit along São Francisco Craton south/south-western edge with similar interpretation on EMAG2 data. Since complete understanding is far from complete, our proposed analogue model for accretion-related evolution takes the syntax zone as the product of a two-fold event, accounting for late-shearing structural imprint. This analogue model takes basis in Jamieson and Beaumont (2013) PURC systematic for accretion since Proterozoic times (at least) in disagreement to pure fold and thrust belt proposals (Campos Neto et al. 2011, Trouw et al. 2013).

From the geophysical perspective the outline of the Alterosa Suture zone still demands further scrutiny allied by field work and, maybe, by other geophysical surveys. This work presents an alternative to current views and stands to be proven by information other than geophysics - relying in the supportive nature of the geophysical datasets - absent of trueness by itself.

\section{ACKNOWLEDGEMENTS}

JGM is thankful to Conselho Nacional de Desenvolvimento Cientifico e Tecnológico (CNPq) - "National Counsel of Technological and Scientific Development" financial support during its time as Master' student in Programa de pós-graduação em Geociências e Meio Ambiente (Graduate school on Geosciences and Environment), IGCE-UNESP- Brazil. Support by Eder Molina and Yara Marangoni from University of São Paulo (USP) - Institute of Astronomy, Geophysics and Atmospheric Sciences was remarkably important for this work. Luiz Sérgio Amarante Simóes from Department of Petrology and Metallogeny at IGCE-UNESP- Brazil deserves our thanks for discussions on the subject. We are thankful for the editor in chief and anonymous reviewers that discussed the subject and suggested important changes in the manuscript.

\section{REFERENCES}

Abbott D.H., Mooney W.D., VanTongeren J.A. 2013. The character of the Moho and lower crust within Archean cratons and the tectonic implications. Tectonophysics, 609:690-705. doi: 10.1016/j. tecto.2013.09.014

Alkmim F.F., Brito Neves B.B., Alves J.A. 1993. Arcabouço tectônico do Cráton do São Francisco - uma revisão. In: Simpósio sobre o Cráton do São Francisco e suas Faixas Marginais, Salvador. p. 72-77.

Almeida F.F.M., Brito Neves B.B., Dal Ré Carneiro C. 2000. The origin and evolution of the South American Platform. Earth-Science Review, 50:77-111. doi: 10.1016/S0012-8252(99)00072-0

Almeida F.F.M., Hasui Y., Brito Neves B.B., Fuck R. A. 1981. Brazilian structural provinces: an introduction. Earth-Science Review, 17:1-29. doi: 10.1016/0012-8252(81)90003-9

Assumpção M., Bianchi M., Julià J., Dias F.L., Sand França G., Nascimento R., Drouet S., Pavão C.G., Albuquerque D.F., Lopes A.E.V. 2013a. Crustal thickness map of Brazil: Data compilation and main features. Journal of South American Earth Sciences, 43:74-85. doi: 10.1016/j.jsames.2012.12.009
Assumpção M., Feng M., Tassara A., Julià J., 2013b. Models of crustal thickness for South America from seismic refraction, receiver functions and surface wave tomography. Tectonophysics, 609:82-96. doi: 10.1016/j.tecto.2012.11.014

Blakely R.J. 1996. Potential theory in gravity and magnetic applications. Cambridge University Press, Cambridge.

Bizzi, L.A., Schobbenhaus, C., Vidotti, R.M., Gonçalves, J.H., 2003. Geologia, Tectônica e Recursos Minerais do Brasil: texto, mapas e SIG. CPRM, Brasília.

Boyer S.E., Elliott D. 1982. Thrust systems. American Association of Petroleum Geologists Bulletin, 66:1196-1230.

Briggs I.C. 1974. Machine contouring using minimum curvature. Geophysics, 39:39-48.

Brito Neves B., Cordani U. 1991. Tectonic evolution of South America during the late Proterozoic. Precambrian Research, 53:23-40. doi: 10.1016/0301-9268(91)90004-T 
Brito Neves B.B., da Costa Campos Neto M., Fuck R. A. 1999. From Rodinia to western Gondwana: an approach to the Brasiliano-Pan African cycle and orogenic collage. Episodes, 22:155-166.

Brito Neves B.B., Fuck R.A. 2013. Neoproterozoic evolution of the basement of the South-American platform. Journal of South American Earth Sciences, 47:72-89. doi: 10.1016/j.jsames.2013.04.005

Brito Neves B.B., Fuck R.A. 2014. The basement of the South American platform: Half Laurentian (N-NW) + half Gondwanan (E-SE) domains. Precambrian Research, 244:75-86. doi: 10.1016/j. precamres.2013.09.020

Campanha G.A.C., Brito Neves B.B. 2004. Frontal and Oblique Tectonics in the Brazilian Shield. Episodes, 27(4):255-259. Available from: $\quad<$ https://www.researchgate.net/publication/279595384 Frontal_and_oblique_tectonics_in_the_Brazilian_shield>

Campos Neto M.D.C., Basei M.A.S., Assis Janasi V., Moraes R. 2011. Orogen migration and tectonic setting of the Andrelândia Nappe system: an Ediacaran western Gondwana collage, south of São Francisco craton. Journal of South American Earth Sciences, 32:393-406. doi: 10.1016/j.jsames.2011.02.006

Campos Neto M.D.C., Caby R. 1999. Neoproterozoic high-pressure metamorphism and tectonic constraint from the nappe system south of the Sao Francisco Craton, southeast Brazil. Precambrian Research, 97:3-26. doi: 10.1016/S0301-9268(99)00010-8

Campos Neto M.D.C., Caby R. 2000. Terrane accretion and upward extrusion of high-pressure granulites in the neoproterozoic nappes of Southeast Brazil: Petrologic and structural constraints. Tectonics, 19:669-687. doi: 10.1029/1999TC900065

Campos Neto M.D.C., Janasi V.A., Basei M.A.S., Siga Jr. O. 2007. Sistema de nappes Andrelândia, setor oriental : litoestratigrafia e posição estratigráfica. Revista Brasileira de Geociências, 37:47-60.

Carmichael R. 1989. Physical properties of rocks and minerals. Florida, CRC Press Inc.

Cawood P.A., Kroner A., Collins W.J., Kusky T.M., Mooney W.D., Windley B.F. 2009. Accretionary orogens through Earth history. Geological Society of London, 318:1-36. doi: 10.1144/SP318.1

Chulick G.S., Detweiler S., Mooney W.D. 2013. Seismic structure of the crust and uppermost mantle of South America and surrounding oceanic basins. Journal of South American Earth Sciences, 42:260-276. doi: 10.1016/j.jsames.2012.06.002

Cordani U.G., Sato K. 1999. Crustal evolution of the South American Platform, based on $\mathrm{Nd}$ isotopic systematics on granitoid rocks. Episodes, 22:167-173.

Coward M. 1983. Thrust tectonics, thin skinned or thick skinned, and the continuation of thrusts to deep in the crust. Journal of Structural Geology, 5:113-125. doi: 10.1016/0191-8141(83)90037-8

Coward M. 1994. Continental collision. In: Hancock P.L. (Ed.). Continental Deformation. Oxford, Pergamon Press Ltd., p. 264-288.

Davison I. 1994. Linked fault systems: extensional, strike slip and contractional. In: Hancock, P.L. (Ed.). Continental Deformation. Oxford, Pergamon Press Ltd., p. 121-142.

Durrheim R.J., Mooney W.D. 1991. Archean and Proterozoic crustal evolution: evidence from crustal seismology. Geology, 19:606-609.

Durrheim R.J., Mooney W.D. 1994. Evolution of the Precambrian lithosphere: Seismological and geochemical constraints. Journal of Geophysical Research, 99:15359-15374. doi: 10.1029/94JB00138

Ebert H.D., Chemale Jr. F., Babinski M., Artur A.C., van Schmus W.R. 1996. Tectonic setting and U/Pb zircon dating of the plutonic Socorro Complex in the Transpressive Rio Paraíba do Sul shear belt, SE Brazil. Tectonics, 15:688-699.
Ebert H.D., Hasui Y. 1998. Transpressional tectonics and strain partitioning during oblique collision between three plates in the Precambrian of southeast Brazil. Geological Society of London, 135:231-252. doi: 10.1144/GSL.SP.1998.135.01.15

França G.S., Assumpção M. 2004. Crustal structure of the Ribeira fold belt, SE Brazil, derived from receiver functions. Journal of South American Earth Sciences, 16:743-758. doi: 10.1016/j. jsames.2003.12.002

Gerya T. 2014. Precambrian geodynamics: Concepts and models. Gondwana Research, 25:442-463. doi: 10.1016/j.gr.2012.11.008

Granot R., Dyment J. 2015. The Cretaceous opening of the South Atlantic Ocean. Earth and Planetary Science Letters, 414:156-163. doi: 10.1016/j.epsl.2015.01.015

Guimarães S.N.P., Ravat D., Hamza V.M. 2014. Combined use of the centroid and matched filtering spectral magnetic methods in determining thermomagnetic characteristics of the crust in the structural provinces of Central Brazil. Tectonophysics, 624-625:87-99. doi: 10.1016/j.tecto.2014.01.025

Haralyi N.L.E., Hasui Y. 1982. The gravimetric information and the Archean-Proterozoic structural framework of eastern Brazil. Revista Brasileira de Geociências, 12:160-166.

Hasui Y. 2010. A grande colisão pré-cambriana do sudeste brasileiro e a estruturação regional. Geociências, 29:141-169.

Hasui Y., Haralyi N.L.E., Costa J.B.S. 1993. Megaestruturação pré-cambriana do território brasileiro baseada em dados geofísicos e geológicos. Geociências, 12:7-31.

Heilbron M., Valeriano C.M., Tassinari C.C.G., Almeida J., Tupinamba M., Siga O., Trouw R. 2008. Correlation of Neoproterozoic terranes between the Ribeira Belt, SE Brazil and its African counterpart: comparative tectonic evolution and open questions. Geological Society of London, 294:211-237. doi: 10.1144/SP294.12

Iyer S.S., Choudhuri A., Pattison D.R.M., De Paoli G.R. 1996. Petrology and geochemistry of the Neoproterozoic Guaxupé granulite facies terrain, southeastern Brazil. Precambrian Research, 77. doi: 10.1016/0301-9268(95)00043-7

Jamieson R.A., Beaumont C. 2013. On the origin of orogens, Bulletin of Geological Society of America, 125:1671-1702. doi: 10.1130/B30855.1

Jessell M., Jessell M. Geophysics K., Geophysics K., 2001. Three-dimensional geological modelling of potential field data. Computers \& Geosciences, 27:455-465.

Jessell M.W., Valenta R.K. 1996. Structural geophysics: Integrated structural and geophysical modelling. Computer Methods in the Geosciences, 15:303-324. doi: 10.1016/ S1874-561X(96)80027-7

Kamber B.S. 2015. The evolving nature of terrestrial crust from the Hadean, through the Archaean, into the Proterozoic. Precambrian Research, 258:48-82. doi: 10.1016/j.precamres.2014.12.007

La Fehr T.R., Nabighian M.N. 2012. Fundamentals of gravity exploration. Tulsa, Society of Exploration Geophysicists.

Lama E.A., Oliveira M.A.F., Zanardo A. 1998. Geochemistry of the Guaxupé Granulites, Minas Gerais, Brazil. Gondwana Research, 1:357-365. doi: 10.1016/S1342-937X(05)70851-0

Lama E.A., Zanardo A., Oliveira M.A.F., Morales N. 2000. Exhumation of high-pressure granulites of the Guaxupé complex, southeastern Brazil. Geological Journal, 35:231-249. doi: 10.1002/gj.859

Laske G., Masters G., Ma Z., Pasyanos M.E. 2012. CRUST1. 0 : an Updated Global Model of Earth's Crust 14. 3743p. 
Lesquer A., Almeida F.F.M., Davino A., Lachaud J.C., Maillard P. 1981. Signification structurale des anomalies gravimetriques de la partie Sud du Craton de São Francisco (Bresil). Tectonics, 76:273-293.

Malagutti Filho W., Ebert H.D., Hasui Y., Haralyi N.L.E., Hackspacher P.C., Sturaro J.R., Souza C.A., Almeida S.H.S. 1996. Gravimetria e compartimentação crustal no sul de Minas Gerais. Geociências, 15:199-217

Mantovani M.S.M., Brito Neves B.B. 2005. The Paranapanema lithospheric block: Its importance for Proterozoic (Rodinia, Gondwana) supercontinent theories. Gondwana Research, 8:303-315. doi: 10.1016/S1342-937X(05)71137-0

Mantovani M.S.M., Quintas M.C.L., Shukowsky W., Neves B. 2005. Delimitation of the Paranapanema proterozoic block: A geophysical contribution. Episodes, 28:18-22.

Marangoni Y.R., Mantovani M.S.M. 2013. Geophysical signatures of the alkaline intrusions bordering the Paraná Basin. Journal of South American Earth Sciences, 41:83-98. doi: 10.1016/j.jsames.2012.08.004

Martins-Neto M. A. 2009. Sequence stratigraphic framework of Proterozoic successions in eastern Brazil. Marine and Petroleum Geology, 26:163-176. doi: 10.1016/j.marpetgeo.2007.10.001

Maus S., Barckhausen U., Berkenbosch H., Bournas N., Brozena J., Childers V., Dostaler F., Fairhead J.D., Finn C., Von Frese R.R.B., Gaina C., Golynsky S., Kucks R., Lühr H., Milligan P., Mogren S., Müller R.D., Olesen O., Pilkington M., Saltus R., Schreckenberger B., Thébault E., Tontini F.C. 2009. EMAG2: A 2-arc min resolution Earth Magnetic Anomaly Grid compiled from satellite, airborne, and marine magnetic measurements. Geochemistry, Geophysics, Geosystems, 10. doi: 10.1029/2009GC002471

Milligan P., Gunn P.J. 1997. Enhancement and presentation of airborne geophysical data. AGSO Journal of Australian Geology $\odot$ Geophysics, 17:63-75.

Mora C.A.S., Campos Neto M.D.C., Basei M.A.S. 2014. Syn-collisional lower continental crust anatexis in the Neoproterozoic Socorro-Guaxupé Nappe System, southern Brasília Orogen, Brazil: Constraints from zircon U-Pb dating, Sr-Nd-Hf signatures and whole-rock geochemistry. Precambrian Research, 255:847-864. doi: 10.1016/j.precamres.2014.10.017

Morales N. 1993. Evolução tectônica do cinturão de cisalhamento Campo do Meio na sua porção ocidental. São Paulo, University of São Paulo.

Nabighian M.N., Ander M.E., Grauch V.J.S., Hansen R.O., LaFehr T.R., Li Y., Pearson W.C., Peirce J.W., Phillips J.D., Ruder M.E. 2005a. Historical development of the gravity method in exploration. Geophysics, 70:63ND-89ND. doi: 10.1190/1.2133785

Nabighian M.N., Grauch V.J.S., Hansen R.O., LaFehr T.R., Li Y., Peirce J.W., Phillips J.D., Ruder M.E. 2005b. The historical development of the magnetic method in exploration. Geophysics, 70:33ND-61ND. doi: 10.1190/1.2133784

Peate D. 1997. The Paraná-Etendeka Province. Geophysical Monograph. 100:217-246.

Percival J.A., Fountain D.M., Salisbury M.H. 1992. Exposed crustal cross sections as windows on the lower crust. In: Fountain D.M., Arculus R., Kay R.W. (Eds.), Continental Lower Crust (Developments in Geotectonics 23). Amsterdam, Elsevier, p. 317-362.

Peternel R., Allard R., Trouw J., Da R., Schmitt S. 2005. Interferência entre duas Faixas Móveis Neoproterozóicas : o caso das faixas Brasília e Ribeira no Sudeste do Brasil. Revista Brasileira de Geociências, 35:297-310. doi: 10.5327/rbg.v35i3.1170

Romano R., Lana C., Alkmim F.F., Stevens G., Armstrong R. 2013. Stabilization of the southern portion of the São Francisco craton, SE Brazil, through a long-lived period of potassic magmatism. Precambrian Research, 224:143-159. doi: 10.1016/j.precamres.2012.09.002
Sanderson D. 1984. Transpression. Journal of Structural Geology, 6:449-458. doi: 10.1016/0191-8141(84)90058-0

Shive P.N., Blakely R.J., Frost B.R., Fountain D.M. 1992. Magnetic properties of the lower continental crust. In: Fountain D.M., Arculus R., Kay R.W. (Eds.), Continental Lower Crust (Developments in Geotectonics 23). Amsterdam, Elsevier, p. 145-177.

Sial A.N., Dall'Agnol R., Ferreira V.P., Nardi L.V.S., Pimentel M.M., Wiedemann C.M. 1999. Precambrian granitic magmatism in Brazil. Episodes, 22:191-198.

Simões L.S.A. 1995. Evolução tectonometamórfica da Nappe de Passos, sudeste de Minas Gerais. São Paulo, Universidade de São Paulo.

Skeels D.C. 1947. Ambiguity in gravity interpretation. Geophysics, 12:43-56. doi: 10.1190/1.1437295

Slavec G.D.B., Mantovani M.S.M., Shukowsky W. 2004. Estudo gravimétrico do Maciço Alcalino de Poços de Caldas - Minas Gerais. Revista Brasileira de Geociências, 22:88. doi: 10.1590/ S0102-261X2004000100009

Spector A., Grant F.S. 1970. Statistical models for interpreting aeromagnetic data. Geophysics, 35:293-302.

Stampfli G.M., Hochard C., Vérard C., Wilhem C., von Raumer J. 2013. The formation of Pangea. Tectonophysics, 593:1-19. doi: 10.1016/j. tecto.2013.02.037

Stewart J.R., Betts P.G. 2010. Implications for Proterozoic plate margin evolution from geophysical analysis and crustal-scale modeling within the western Gawler Craton, Australia. Tectonophysics, 483:151-177. doi: 10.1016/j.tecto.2009.11.016

Strieder A.J., Suita M.T.D.F. 1999. Neoproterozoic geotectonic evolution of Tocantins Structural Province, Central Brazil. Journal of Geodynamics, 28:267-289. doi: 10.1016/ S0264-3707(98)00042-8

Sylvester A.G. 1988. Strike-slip faults. Geology Society of America Bulletin, 100:1666-1703.

Talwani M., Worzel J.L., Landisman M. 1959. Rapid gravity computations for two-dimensional bodies with application to the Mendocino submarine fracture zone. Journal of Geophysical Research, 64:49-59. doi: 10.1029/JZ064i001p00049

Teixeira W., Figueiredo M.C.H. 1991. An outline of Early Proterozoic crustal evolution in the São Francisco craton, Brazil: a review. Precambrian Research, 53:1-22. doi: 10.1016/0301-9268(91)90003-S

Telford W.M., Geldart L.P., Sheriff R.E. 1990. Applied Geophysics, 2nd edition. Cambridge, Cambridge University Press.

Thomas J.L., Direen N.G., Hand M. 2008. Blind orogen: Integrated appraisal of multiple episodes of Mesoproterozoic deformation and reworking in the Fowler Domain, western Gawler Craton, Australia. Precambrian Research, 166:263-282. doi: 10.1016/j. precamres.2007.05.006

Trompette R.R., Uhlein A., Egydio-Silva M., Karmann I. 1992. The Brasiliano São Francisco craton revisited (central Brazil). Journal of South American Earth Sciences, 6:49-57. doi: 10.1016/0895-9811(92)90016-R

Trouw R.J., Peternel R., Ribeiro A., Heilbron M., Vinagre R., Duffles P., Trouw C.C., Fontainha M., Kussama H.H. 2013. A new interpretation for the interference zone between the southern Brasília belt and the central Ribeira belt, SE Brazil. Journal of South American Earth Sciences, 48:43-57. doi: 10.1016/j. jsames.2013.07.012

Turcotte D.L., Schubert G. 2002. Geodynamics, 2nd edition. Cambridge, Cambridge University Press. 
Ulbrich H.H.G.J., Gomes C.B. 1981. Alkaline rocks from continental Brazil. Earth-ScienceReview, 17:135-154. doi:10.1016/0012-8252(81)90009-X

Valeriano C.M., Pimentel M.M., Heilbron M., Almeida J.C.H., Trouw R.J. 2008. Tectonic evolution of the Brasilia Belt, Central Brazil, and early assembly of Gondwana. Geology Society of London, 294:197-210. doi: 10.1144/SP294.11

van der Meijde M., Fadel I., Ditmar P., Hamayun M. 2015. Uncertainties in crustal thickness models for data sparse environments: A review for South America and Africa. Journal of Geodynamics, 84:1-18. doi: 10.1016/j.jog.2014.09.013

van der Meijde M., Julià J., Assumpção M. 2013. Gravity derived Moho for South America. Tectonophysics, 609:456-467. doi: 10.1016/j. tecto.2013.03.023

Wessel P., Smith W.H.F. 2013. Generic Mapping Tools: Improved version released. EOS Trans. AGU, 94:409-410.

Westin A., Campos Neto M.D.C. 2013. Provenance and tectonic setting of the external nappe of the Southern Brasilia Orogen. Journal of South American Earth Sciences, 48:220-239. doi: 10.1016/j.jsames.2013.08.006
Windley B.F. Tarney J. 1986. The structural evolution of the lower crust of orogenic belts, present and past. Geological Society of London, 24:221-230. doi: 10.1144/GSL. SP.1986.024.01.20

Won I.J., Bevis M. 1987. Computing the gravitational and magnetic anomalies due to a polygon: Algorithm and Fortran subroutines. Geophysics, 52:232-238

Woodcock N.H., Fischer M. 1986. Strike-slip duplexes. Journal of Structural Geology, 8:725-735. doi: 10.1016/0191-8141(86)90021-0

Woodcock N.H., Schubert C. 1994. Continental strike-slip tectonics. In: Hancock P.L. (Ed.), Continental deformation. Oxford, Pergamum Press Ltd., p. 251-264.

Zalan P.V., Wolff S., Astolf M.A.M., Vieira I.S., Conceição J.C.J., Appi V.T., Santos Neto E.V., Cerqueira J.R., Marques A. 1990. The Parana Basin, Brazil: Chapter 33: Part II. Selected Analog Interior Cratonic Basins: Analog Basins, 134:681-708.

Available at www.sbgeo.org.br 